\title{
Charting the Development of Knowledge on Soviet and Post-Soviet Education through the Pages of Comparative and International Education Journals
}

\author{
Maia Chankseliani ${ }^{1}$ \\ Department of Education, University of Oxford, 15 Norham Gardens, OX26PY, \\ Oxford, $U K$
}

\begin{abstract}
This paper examines 126 research articles from three comparative education journals to chart the development of knowledge within comparative education on the Soviet Union and postSoviet countries. Thematic, theoretical, discursive and methodological aspects of scholarship are linked with changing geopolitical realities in a systematic analysis of scholarship published since the late 1950s. A new framework of multi-layered colonialism is introduced to explore different features of the double disadvantage that comparative education knowledge production on post-Soviet countries has faced - Russian imperialism and Western academic colonialism. The paper contributes to comparative education knowledge creation by historicising our understanding of Western academic output and outlining a potential future direction in the development of knowledge on post-Soviet systems, policies, and practices of education.
\end{abstract}

\section{Keywords}

Comparative and international education, multi-layered colonialism, Soviet Union, postSoviet countries, ethnocentrism

\section{Introduction}

Although the work of the founding fathers of comparative education in the USA - such as William Johnson, George Bereday, George Counts, and William Brickman - overemphasised Soviet studies, contemporary research on education policies and practices in post-Soviet countries is not expansive. This article problematizes comparative education knowledge production on Soviet and post-Soviet education by interrogating the ethnocentric nature of the scholarship and demonstrating a lack of inclusion of indigenous intellectual work. This paper develops a historical sense of the comparative education field pertaining to the study of post-Soviet countries, so that we expand our awareness of the field to which we belong and to which we aim to contribute. For this purpose, I reviewed all research articles in The Comparative Education Review (CER), Comparative Education (CE), and Compare: A Journal of Comparative and International Education (Compare) since their first issues were published. As a meta-analytical effort, this study may have limited immediate relevance for policy or practice. The main contribution of the study is academic; it intends to advance the debates on comparative education knowledge production intellectually and methodologically

\footnotetext{
${ }^{1}$ E-mail: maia.chankseliani@education.ox.ac.uk; telephone: (+44) 01865611011
} 
Comparativists' preoccupation with this region reached a peak in the 1950s and 1960s, soon after the oldest journal in the field - CER - was first published in 1957 in the USA. The American interest in Soviet education stemmed from the competition that the Cold War engendered. The launch of Sputnik, according to Harold Noah, was the major event demonstrating to Americans that the Soviets had a 'fantastically superior' system of general and technical education (Steiner-Khamsi 2006c, 10). The Sputnik launch in 1957 'set in motion furious efforts by Americans to reexamine their system of education. The tendency was to point to Soviet progress in science, particularly in space science, as a reflection of achievements made by the Soviet School' (Jahn 1975, 455). During the heyday of the Western interest in Soviet education, the USA and other Western countries invested heavily in the study of the Soviet education system. In the first three years following the launch of Sputnik approximately 300 articles, books, and booklets were published on Soviet education in the USA (Rosen 1964, 153). A book titled What Ivan Knows That Johnny Doesn't (Trace 1961) epitomised the mood of that era.

The Union of Soviet Socialist Republics (USSR) implemented a number of educational reforms in the period from the late 1950s to the late 1970s. However, the core characteristics of the Soviet system of education did not change; continuity in education policy direction was retained, as the country followed the goals set by Lenin in the first quarter of the $20^{\text {th }}$ century (Grant 1992; Tomiak 1986). The rise of Gorbachev and the Perestroika movement in the 1980s and independence movements in the Soviet Socialist Republics led to the dissolution of the USSR in 1991; this resulted in the emergence of fifteen independent states and signified the end of the Cold War.

Soviet education turned from being an object of admiration to one of antipathy in the 1970s and 1980s, when more information became available on political repressions and the economy of shortage (Steiner-Khamsi 2006b). The interest in Soviet education, as measured by the number of research articles published in the three journals, declined in the 1990s and early 2000s until the reawakening of enthusiasm in the mid-2000s (Figure 1).

Figure 1.

While American interest in Soviet education seems to have been much stronger than European interest in the 1950s-1970s, the subsequent preoccupation with post-Soviet countries was lower in the American journal than in the European ones. Since the 1980s, $C E R$ has published 20 articles with a focus on post-Soviet countries while Compare has published 23 articles, and $C E 29$ articles. Amongst European countries, the Federal Republic of Germany was particularly keen on the academic study of (post-)Soviet education. The 1960s and 1970s saw a considerable expansion of state-funded research on Soviet education in Germany. Berlin, Bochum, and Marburg housed university-based research teams working on Soviet education. The German Institute for International Educational Research in Frankfurt was another important centre. German interest in (post-)Soviet education was sustained long after the 1970s which indicates that it might not have been 'remorselessly linked to the whims of the general political situation' (Kuebart 1989, 285). Two significant figures in Germany, Oscar Anweiler and Wolfgang Mitter, were pioneers in research on education in the Soviet Union and the eastern bloc. The following three reasons may explain the continuous engagement of German comparativists with Soviet education. First, the perception that the USSR owed its political, economic and scientific development to 'a remarkable expansion in education' and Germans wanted to learn about the efficiency of the Soviet school system (Mitter 1973, 34). Second, Germany was divided into two parts, one 
of which was in the Soviet sphere of influence. Third, comparative education was attached to university chairs which helped to make the academic study of the region more sustainable (Kuebart 1989). A number of journal articles by Oscar Anweiler (1965; 1975), Wolfgang Mitter $(1973 ;$ 1987; 2004), and Friedrich Kuebart (1989) were published in CE, Compare, and CER and are included in the analysis that follows.

This paper starts by a brief outline of the procedure employed for the selection of articles for analysis. The subsequent overview of the disciplinary and thematic foci of the articles precedes the main section of the article on multi-layered colonialism. This section includes the definition of the new concept of multi-layered colonialism and the analysis of the articles using this concept. Methodological aspects of the papers as well as the issues related to the data collection/availability and interpretation are considered. The 'discourse of particularity' and the 'discourse of universality' are identified in the scholarship under scrutiny. This aids the investigation of the level and type of theoretical engagement that comparativists have demonstrated in relation to the study of (post-)Soviet education policies and practices. The paper ends with contemplation on the potential ways of moving the field forward.

\section{Selection of Articles}

This study uses the evidence from the systematic analysis of 126 journal articles from three journals in comparative education: The Comparative Education Review, Comparative Education, and Compare: A Journal of Comparative and International Education. These three journals were selected as some of the most reputable international peer-reviewed research journals in the field of comparative education. CER is the official journal of the Comparative and International Education Society. Compare is the official journal of the British Association for International and Comparative Education. The oldest journal in the field - CER - was founded in 1957; CE followed in 1964, and Compare in 1975.

In each journal, I ran seventeen separate searches with the following words: Soviet, Azerbaijan, Armenia, Belarus, Estonia, Georgia, Kazakhstan, Kyrgyzstan/Kyrgyz Republic, Latvia, Lithuania, Moldova, Russia, Tajikistan, Turkmenistan, Ukraine, and Uzbekistan. The online search for articles (conducted on 8 June 2015) produced 866 results from CER, 361 results from $C E$, and 154 results from Compare. Book reviews, essay reviews, bibliographies, editorials, statistical summaries, and reports on events were discarded. Articles that mentioned the USSR or post-Soviet countries only in passing were also excluded. Overall, 126 research articles were selected for the subsequent analysis: 59 articles from $C E R, 40$ articles from $C E$, and 27 articles from Compare. These articles examined the USSR, one or several Soviet Socialist Republics, or post-Soviet countries. CER had the highest ratio of number of articles per year it has been in print - on average, one article per year. The ratio for $C E$ was 0.77 , and the ratio for Compare was $0.66 .^{2}$

\section{Disciplinary and Thematic Foci}

The articles analysed covered 15 different disciplines: education, political science, sociology, economics, history, law, agriculture, demography, geography, psychology, philosophy, sports studies, religious studies, linguistics/philology, and management studies/information technologies. The disciplinary foci were assessed based on the scholarly literature that each article was embedded in. Besides education studies, the following disciplines emerged as the most popular: political science (44\% of all articles), sociology (43\%), economics (20\%), and history (13\%). The absolute majority of the articles were interdisciplinary and pertained to more than one group. Disciplinary foci have been changing over time. In the post-1991

\footnotetext{
${ }^{2}$ CER - 59 years (1957-2015) / 59 articles; CE - 52 years (1964-2015) / 40 articles; Compare - 41 years (1975-2015) / 27 articles.
} 
period, the proportion of articles placed in the political science literature doubled and the proportion of articles situated in historical scholarship tripled (Figure 2).

Figure 2.

Analysis of two to five keywords from each article and the main words from the article titles showed that the most frequently occurring words for the pre-1980s period were related to labour, teachers, higher education and polytechnic education; essentially, it was primarily about Soviet teachers and schools serving workforce development to meet the needs of the planned economy. Some articles also examined ideology, propaganda, and indoctrination. In the 1980s, the main foci remained generally the same, with the addition of perestroika and social issues related to class, inequality, stratification, and minorities. The picture was different in the post-1991 period. Transition, history teaching, national identity, and the language of instruction become the keywords together with higher education. Overall, analysis of the keywords showed that the thematic foci shifted from workforce development to issues of identity and transition. Across all time periods, there was an overwhelming interest in textbooks.

Some of the key developments in the Soviet and post-Soviet systems were invisible in the articles analysed. For example, the reform of the USSR school curriculum in the early 1970s which introduced a lot of high level, abstract maths concepts in early years schooling and which was allegedly unmanageable for the majority of children (Nikandrov 1989). Another example would be educational borrowing - following the dissolution of the USSR, an influx of foreign aid and the opening of borders, borrowing and adaptation of educational policies and practices from other countries became a viable option for generating ideas for reforming educational systems. ${ }^{3}$ Resistance to change was another relevant topic generally overlooked in the articles in the post-1991 period. Few articles analysed educational leadership, changes in vocational education and training in the post-1991 period, geographic inequalities, and privatisation/marketisation of education. The main focus since the dissolution of the USSR has been placed on classroom practice and related issues such as textbooks, language education or multi-lingual education.

\section{Multi-layered Colonialism}

Immersion into the selected 126 research articles published in the last six decades exposed me to a curious pattern of knowledge creation on (post-)Soviet countries where the voices of locals are barely heard and indigenous theories rarely utilised. The analysis consistently demonstrated the dominance of Western academic thought and a Russia-centred empirical approach.

Colonialism as a practice of domination of one country over other countries acquires a new meaning when discussed in the context of the development of comparative education knowledge on (post-)Soviet states. I introduce a new concept of multi-layered colonialism to analyse this phenomenon. Figure 3 presents a simplified model of multi-layered colonialism where Russian imperialism is differentiated from Western academic colonialism. Fourteen post-Soviet countries colonised by the Russian empire and the USSR that succeeded it are placed in the centre of the figure. The coloniser - the Russian Empire, later Soviet Russia, and

\footnotetext{
${ }^{3}$ Only two studies looked at borrowing in the post-Soviet context Lisovskaya and Karpov (1999) and Elliott and Tudge (2007).
} 
currently the Russian Federation - is represented by the black circle around the post-Soviet countries. The outer circle stands for Western academia.

Figure 3.

In terms of world-systems theory, Russia is a semi-periphery (Babones 2013) that acts in part 'as a peripheral zone for core countries and in part [...] as a core country for some peripheral areas' (Wallerstein 1976, 463). While being a core country for post-Soviet states, Russia is a peripheral country for other Western core countries. This central position in the region and the Western interest to Russia vis-à-vis other post-Soviet countries may stem from Russia's political and economic role in the Russian empire and the USSR, as well as its size and wealth (Chankseliani 2015).

Although it has been argued that post-communist countries have been neglected in Western postcolonial studies (Kołodziejczyk and Şandru 2012; Moore 2006), there exists a substantial body of scholarship that recognises the Russian empire and the USSR that succeeded it as comparable to other European colonial empires. ${ }^{4}$ The historical reality that the Soviet Union to which Russia was a successor and the legal heir - was a coloniser is overlooked in the absolute majority of the articles analysed.

Colonialism may be studied by either employing colonialism as a variable that is included in a sociological inquiry or by using non-Western knowledge in order to 'capture the felt experiences of colonialism, the voice and agency of colonized people, and the dilemmas and pathways of postcolonial societies' (Go 2012, 39-40). Based on this differentiation, I introduce a binary typology: Type I are studies that use colonialism as a variable and Type II are studies that go a step further by utilising indigenous theories and voices to capture experiences of colonialism. The following three articles were classified under type I studies as they dealt with colonial themes: the study by Carolyn Kissane (2005) on history education in post-socialist Kazakhstan, the article by Iveta Silova, Mark Johnson, and Stephen Heyneman (2007) on the crisis of social cohesion in Azerbaijan and Central Asia. And that of Raija Kemppainen, Scott Ferrin, Steven Hite and Sterling Hilton (2008) on Russian-speaking parents' choice of language of instruction for their children in Estonia.

The USSR expanded its political influence by implementing a number of Russification policies. These included imposing the Russian language as the lingua franca, facilitating the resettlement of ethnic Russians to the colonised countries, rewriting the history curriculum and textbooks, and educating selected individuals in the colonial capital to develop human resources that would serve the colony in the future. Russification policies weakened national identity in many post-Soviet nation-states including Kazakhstan (Kissane 2005). In the article published in $C E$, Kissane (2005) examined 'de-Sovietized-re-Kazakhified' national identity and acknowledged that history textbooks written by the Soviet authorities represented 'Russian colonial conquests of the Republics' as 'voluntary and friendly annexations'; textbooks portrayed 'Soviet colonization and industrialization' only in a positive light (p. 48). De-Sovietisation and de-Russification processes, that started following the dissolution of the USSR, involved the protection of national interests against the colonial other by removing Soviet symbols, institutions and the Russian language as the

\footnotetext{
${ }^{4}$ See, for example, Carey and Raciborski (2004), Ferro (1997), Kappeler (2001), Khalid (2007), Lazarus (2012), Moore (2006)
} 
primary language of communication (p. 51). What remained to be accomplished was depoliticisation and de-ideologisation of the history curriculum (Kissane 2005, 66).

Language issues in Central Asia and Azerbaijan was explored by Silova et al. (2007) in an article published in CER. The article pointed to the negative aspects of an abrupt shift from Russian to native languages of instruction: most teachers and teaching materials became obsolete and there was no adequate financial support to help teachers and schools.

Referring to the decolonisation and post-colonialism experiences of Asia and Africa in the 1960s, the authors suggested that 'a more staged approach and the possible retention of the lingua franca, at least in higher education' would have been more appropriate' (173).

The word colony originates from the Latin word colonus [farmer]. The etymology of the word is a reminder that colonial subjugation often involved transfer of people from the colonial power to a new territory. The article by Kemppainen et al. (2008) article published in CER examined the massive influx of the ethnically Russian population in Estonia as part of the Russian colonisation agenda and analysed the factors that were associated with how following independence Russian-speaking parents made a choice of language of instruction for their children.

Type II studies were conspicuously missing amongst the journal articles included in this analysis. Studies that utilise indigenous theories and voices to capture experiences of colonialism might have a potential of indigenisation, which means generating new theory and research that originates from non-Western writing and post-colonial experiences (Go 2012). Local as well as Western discourses and theories on (post-)colonialism could have provided ample material for discussing some of the challenges that the colonised and transition societies in the centre of Figure 3 faced at different times. This area remains unexplored in the three CIE journals.

The outer layer of the concentric circle (Figure 3) refers to western academic colonisation. The early driver of the Western academic interest in the region was the money that became available for studying the USSR and in particular the core country in the region - Russia. The Cold War period, and specifically the 1950s to 1970s in the USA and in subsequent years in Europe, was the time when a lot of financial resources were poured into Soviet studies. The National Defense Education Act (NDEA) (that came into effect in 1958 and funded language training and area studies at universities) and the Ford Foundation actively promoted Soviet studies. USAID was another big funder. Some of the US-funded projects were considered highly contentious:

The air of disenchantment surrounded other aspects of American foreign policy, notably, of course the Vietnam War. By association, American educational influence came under attack in some nations as "academic colonialism." Similarly, American social science research efforts in general were sometimes viewed with covert suspicion as agencies of the American military governmental-industrial establishment and sometimes with open hostility as under-cover enterprises of the C.I.A. (Butts 1968, 1)

According to Harold Noah, the NDEA greatly benefited the development of comparative and international studies in general and Soviet studies in particular (Steiner-Khamsi 2006c, 10). 'The money came pouring in for Soviet studies at U.S. universities because the big question was: How did the Soviet Union ever manage to do this?' recollects Harold Noah (SteinerKhamsi 2006c, 10). Noah also argues that although the preoccupation with Soviet education did not have any impact on the field of comparative and international education, 'the fascination with Soviet education [...] helped improve access to money for research. Both 
comparative and development studies certainly profited from the infusion of funds' (SteinerKhamsi 2006c, 16). ${ }^{5}$

Who were the authors producing comparative education knowledge on (post-)Soviet countries since the late 1950s? The absolute majority (71\%) of the articles' first authors were based at institutions in high-income countries outside the (post-)Soviet space and had no links with the USSR or Eastern Europe $;^{6}$ I refer to these authors as Western authors. On average, $11 \%$ of the first authors had biographical links with Eastern Europe, and $18 \%$ with the USSR/post-Soviet countries. The proportion of authors with links to the USSR or a postSoviet country rose from $13 \%$ in the 1950 s- 1970 s to $24 \%$ in the post- 1991 period. ${ }^{7}$ The absolute majority of the authors from the latter category were linked to Russia, resulting in notable underrepresentation of local voices from other (post-)Soviet countries. Russia, the most powerful state in the region, was the centre of interest for the absolute majority of Western comparativists who form the largest group of the first authors of the articles analysed. By focusing on Russia (32 articles analysed), scholarship published in the three journals has largely ignored the empirical realities of the fourteen colonised countries (the centre of the concentric circle (Figure 3). The 32 articles do not include the papers that claimed they examined Soviet education as such. In fact, a number of the articles in the latter group looked at the Russian Soviet Socialist Republic only while making contentious generalisations about the entire Soviet Union. ${ }^{8}$ Such generalisations faced the possibility of being extremely inaccurate. From the analysed articles, only one featured Armenia; three focused on Kyrgyzstan; two looked at Tajikistan; another two examined Azerbaijan; Georgia, Belarus, and Uzbekistan were the focus of four articles each.

Considering that the absolute majority of the authors had limited language skills and no biographical links with the region, it may not be surprising to encounter cases of ethnocentrism in the articles analysed. Ethnocentrism has been recognised as a major problem in comparative education research (Marginson and Mollis 2001), as scholars often use their own cultural lenses when designing studies, reporting findings, and reviewing the work of others. The idea that it is difficult to avoid one's own cultural lenses when examining social scientific issues originates from the constructivist tradition, e.g. Martyn Hammersley and Paul Atkinson (1996). According to that tradition, knowledge production is integral to the subjective involvement of a researcher with the topic of research and the field of study (Takayama 2011). Some articles on the (post-)Soviet context(s) reveal

\footnotetext{
${ }^{5}$ Not everyone, however, shares the view that comparative study of Soviet education did not have any impact on the development of the field. For example, Gita Steiner-Khamsi (2006b) argues that the Cold War influenced several characteristics of American and German comparative and international education; she mentions the dominance of area studies and international development in American CIE and the absence of development studies in German comparative education (Steiner-Khamsi 2006b, 22-23).

${ }^{6}$ I grouped authors into three categories: USA, Western Europe/Canada/Israel /Australia; Eastern Europe; and post-Soviet countries. Those who originally come from Eastern Europe but worked in the first category countries were coded as Eastern European. For example, George Bereday and Joseph Zajda were coded as Eastern European because of their Polish origin. All those who come from postSoviet countries and work in the first category countries were coded as post-Soviet. For example, Nicholas Hans was coded as post-Soviet because of his Russian origin and Iveta Silova was coded as post-Soviet because of her Latvian origin.

${ }^{7}$ The proportions differed by journal. Compare had the highest concentration (74\% of all articles analysed) of authors from institutions located in the USA, Western Europe, Canada, Israel, Australia or HK, who did not have biographical links with the region. $C E R$, on the other hand, had the highest concentration (20\% of all article analysed) of authors from post-Soviet countries per se.

${ }^{8}$ See, for example, Bigelow (1961), Dobson and Swafford (1980), Yanowitch and Dodge (1968).
} 
criticism of the models of schooling in the USSR and of Soviet social scientific research, as well as the trend of publishing the work of those academics who adopt or situate their work in Western literatures, discourses, and/or frameworks. Below is an example of falling into an ethnocentric trap when describing Uzbek schooling as not of high quality because of being based on much local lore:

In the higher school, madrasa, a broader curriculum was offered. In addition to religion, jurisprudence, philosophy [...], and literature were part of the program. These subjects were not, however, conducted on a very high level, and consisted of much local lore, legend, and impressions of what the outside world and the creation were like. (Medlin and Cave 1964, 170)

Moreover, these authors praise the modernising power of Soviet colonial system for its 'accomplishments' in Uzbekistan to the degree that it is not a 'backward society' like Afghanistan and Iran; and by backwardness the authors mean illiteracy as well as embeddedness in the past:

The transition of Uzbekistan from an overwhelmingly agrarian, technologically undeveloped society to a rapidly industrializing one with dynamic programs for change must be classified as a major achievement of the Soviet system. To gain some perspective into the enormity of this accomplishment, one need look no further than those countries contiguous to the Uzbek Republic; Afghanistan and Iran. While they cannot be equated nor compared uncritically with Uzbek society, both have a great deal in common with Uzbekistan, particularly with regard to religious ideology, ethnic composition, and cultural history. Yet, for the most part, they remain comparatively backward societies with a high percentage of illiteracy and a persistent philosophical orientation toward the past. (Medlin and Cave 1964, 172)

Studies undertaken in the USSR were viewed by some authors as methodologically inferior to Western ones. Richard Dobson and Michael Swafford (1980) argue that V. G. Gendel's research on the educational plans of eighth and tenth graders in central Russia is 'among the best studies on educational attainment conducted by Soviet sociologists' (253). However, Dobson and Swafford also indicate that the study is 'modest by Western standards' (254), without explaining what exactly was meant by 'Western standards', why exactly the study did not meet these standards, or why a study produced outside Western academia was expected to necessarily meet 'Western standards'.

Limited access to the field could have been one of the contributing factors to the production of ethnocentric scholarship, especially in the period when the interest in studying the region was quite high and when the borders of the USSR were strictly controlled. The absolute majority of authors published pre-1991 were based outside the USSR and mainly relied on three sources of data: statistics published by the USSR, newspapers and legal documents, and study tours/visits arranged by different Western institutions in collaboration with their Soviet colleagues.

The USSR statistics were scarce and allegedly dubious. The general approach to Soviet statistics in academic circles was rather sceptical; 'we knew that the published Soviet statistics were far from trustworthy,' says Harold Noah (Steiner-Khamsi 2006c, 13). In some earlier publications, Western authors decide to trust their intuition, when the data are not available, and develop arguments based on the ideas which are not and cannot be supported by evidence. For example, Dixie Harris (1963) makes an inaccurate claim that 'there seems no doubt that minorities [in the USSR] are completing higher education in about the same proportion as the country as a whole' (Harris 1963, 195). In fact, minorities used to be 
underrepresented in Soviet HEIs; a quota system was in place to remediate this problem but quotas were often left unfulfilled because of the shortage of qualified applicants (Perveen 1987; Bailes 2015).

In an interview with Gita Steiner-Khamsi, Beatrice Beach Szekely describes her doctoral dissertation on the topic of the USSR Academy of Pedagogical Sciences as 'close to a disaster' because of extremely limited access to the required data: 'I was not allowed in the archives of the Academy's library in Moscow and tried desperately, using mainly secondary materials, to rely on what dear Harold [...] referred to as "conjecture" ' (Steiner-Khamsi 2006a). The majority of the studies published in the pre-1991 period relied on Soviet statistics in one way or another. There were also cases where authors seemed to have used valid statistics but provided imprecise and unsubstantiated interpretations of the figures. For example, Nathan Kravetz (1980) in his article Education of Ethnic and National Minorities in the USSR uses Soviet statistics to show that the Georgians and Jews have the highest rates of post-primary education attainment. He then argues that this must be because the Georgians have benefited from preferential treatment from Stalin (pp. 15-17). The author's unfamiliarity with the context goes so far as to indicate that Grozny University is in Georgia (p.18). ${ }^{9}$

Study tours provided another source of data. The Comparative and International Education Society organised tours to the USSR in the late 1950s and the 1960s. As Westerners were not particularly welcome in the USSR, their movements within the USSR were strictly controlled. For example, one of the study tours to the USSR, that included visits to three republics and meetings with educators and government officials, took place in 1958 and was followed by a publication of The changing Soviet school: the Comparative Education Society field study in the U.S.S.R (Bereday, Brickman, and Read 1960). The main issue related to the data obtained during study tours is that most of the tour participants did not 'distinguish scrupulously in their reports between what they have seen and what they have been told about the system' (Rosen 1964, 156). The study tours continued in the 1980s and most of these tours revealed almost identical impressions of the Soviet system:

The typical pattern of a lesson which might be shown to a visitor to a Soviet school is as follows: first comes the testing of homework with two or three pupils selected and called to the front of the class to be examined. The lesson continues with exposition of the subject matter by the teacher and ends with the checking of pupils' understanding and the setting of work to be learned for the next lesson. It is unrealistic to imagine that Western visitors to Soviet schools are shown anything other than what is considered good practice. According to most reports, the teaching is competent and efficient of its type but reports of other approaches are rare. Lessons are almost invariably teacherrather than pupil-centred. The furniture and layout of the classroom would not facilitate any other approach; Soviet classrooms always have pairs of desks in rows facing the teacher and the portrait of Lenin. Western observers in Russian schools also report reluctance on the part of the teachers to accept responses differing from what is prescribed by the textbook. (Suddaby 1989, 250)

Little comparative research published in the three journals seems to have been conducted in the (post-)Soviet countries per se, on the ground, involving lengthy qualitative engagement with different groups of population and/or undertaking representative surveys. For example, an article published in $C E$ in 2014 "Using Quantitative Data in World Bank per-Student Funding Reform Projects: Data, Designs and Dilemmas in Transition Countries" examines per-student funding in Bulgaria, Moldova, and Kosovo with few references to local sources of

\footnotetext{
${ }^{9}$ In fact, Grozny University was located in Grozny, the capital of Chechen-Ingush Autonomous Soviet Socialist Republic.
} 
data. Elsewhere, even where articles include references to (post-)Soviet sources, those are mostly to factual or documentary material rather than theoretical ideas. ${ }^{10}$ By mostly relying on the secondary data, most of the papers published in these three journals seem to be far removed from the realities of rural Azerbaijan, metropolitan St Petersburg, or poverty-stricken Tajikistan. Such detachment has contributed to the reproduction of ethnocentric ideas.

Articles published in recent years seem to provide some examples of first-hand research conducted in the region (Hufton, Elliott, and Illushin 2003; Worden 2011; Jankowska 2011). Although some papers still rely on secondary data, large-scale quantitative data are complemented with interviews (Chankseliani 2013; Carnoy, Khavenson, and Ivanova 2015). Most of the articles analysed were theoretically underdeveloped. Those articles that engaged with theory were mostly concentrated on theory testing rather than theory generation. 'While I enjoy the richness of the particular, I am committed to the enterprise of trying to make sense out of the bewildering variety of educational phenomena we observe,' wrote Harold Noah (1984), 'one way that we do this is to take the propositions that arise out of the work done in single countries and test the extent to which they can be said to hold in other situations' (pp. 556-557). Using studies on Japanese education as examples, Takayama (2011) differentiates between two discursive communities of scholars - those drawing on the discourse of particularity when articulating their findings and those employing the discourse of universality. Authors who generate the discourse of particularity rely on nation-specific scholarship produced in the national language and/or in English; these papers tend to be 'disarticulated from the theoretical debates in English-language comparative education and other disciplines in education' (Takayama 2011, 453). The disconnect from theoretical discussions in the relevant fields of educational studies is the main characteristic of this 'closed, "thick" discursive community within which mutual referencing is extensive due to its lack of articulation to wider scholarly communities' (Takayama 2011, 455). According to Takayama's (2011) theory, articles from the discursive community of particularity may be of interest to the English-language 'specialists' of (post-)Soviet education. On the other hand, the work produced by this discursive community helps Anglo-American scholars who undertake purely theoretical work and use such writing as 'raw materials' (Connell 2007, 140) to develop allegedly 'context-free' theoretical scholarship that is applicable to different global contexts (Takayama 2011, 455). Thus, this discursive community benefits those who either specialise in (post)Soviet education or produce theoretical work.

$61 \%$ of all articles (77 out of 126) analysed show the discourse of particularity. These studies generally focus on one country, introducing nationally-specific scholarship to the international scholarly community. For example, Wiloch, Bereday, and Gidynski (1959) on new models of Soviet education, DeWitt (1964) on Soviet economic education, Korbits (2014) on Estonian history textbooks, Karakovsky (1993) on schooling in Russia, Zajda (1979) on education for labour.

Although Takayama acknowledges that the discourse of particularity is sometimes an 'introductory writing' produced by leading academics (Takayama 2011,454), he argues that these scholars act as area specialists in the world system of division of academic labour that favours Anglo-American scholarship and considers 'other' academics' knowledge limited and localised. These scholars, therefore, may not be participating in theoretical knowledge production $^{11}$ which remains the prerogative of the discursive community of universality. Following this stream of thought, one would hypothesise that the majority of those producing

\footnotetext{
${ }^{10}$ For example, Glanzer (2009), Grant (1975), Hogan-Brun (2007), Jahn (1975), McLean (1992).

${ }^{11}$ This is argued by Ben-Ari and van Bremen $(2005,17)$, Connell $(2007,44)$, Kuwayama $(2004,55)$, and Takayama $(2011,456)$
} 
the discourse of particularity are biographically linked to (post-)Soviet countries or Eastern Europe. That is not what the evidence suggests. $71 \%$ of the articles using the discourse of particularity are produced by Western ${ }^{12}$ first authors. ${ }^{13}$ Articles that appear in these journals undergo a meticulous review process involving mostly Western academics. Therefore, it may not be surprising that the majority of articles selected for publication, even in the discursive category of particularity, are produced by Western authors.

(Post-)Soviet education systems, policies and practices became a testing site for Western theories or constructs to be validated and refined, so that those theories could become more universalised. For example, the application of McLeish's 1998 model of five phases of transition to the Baltic context (Hogan-Brun 2007) or testing of the neo-institutional theory in the context of post-Socialist Europe (Bodovski, Kotok, and Henck 2014).Focusing on larger theoretical issues instead of specific educational problems within a national context, the knowledge produced by the discursive community of universality aims to have universal applicability by contributing to the global knowledge production in the respective field of education studies. 39\% (49 out of 126) of all articles analysed produce the discourse of universality. According to Takayama's (2011) categorization, the authors of these articles place (post-)Soviet education in the larger theoretical frameworks, conceptual discussions, and debates in English-language comparative education or other fields of education studies, or compare (post-)Soviet contexts to other countries. Across the board, the dominating feature of these articles is principal reliance on Western theories and literature to interpret the scarce, mostly secondary, data or documents. For example, an article "The International Student Movement" (1964, CER) rests on Western assumptions about colonialism; or another study "Changes in Administrative Control and Teacher Satisfaction in England and the USSR" (1994, CER) uses Western constructs of teacher professionalism. Furthermore, an article "Twentieth-Century Transformations in Catalonia and the Ukraine: Ethnic Implications in Education" (1993, CER) on ethnic implications in education uses the work of Rolland G. Paulston and the paper "On the Shoulders of Giants? Global Science, Resource Asymmetries, and Repositioning of Research Universities in China and Russia" (2014, CER) uses the writing of Robert Merton. Have there been local theorists whose work could have been used by these and other comparativistis? Could it be the case that such writing is not linguistically accessible and/or intellectually engaging to those who write about this region in English? Has the writing embedded in local theories not been considered publishable by the editors of these journals? Future research on comparative and international education knowledge creation will need to address these questions.

Some articles analysed do engage with theories that grew from local contexts, such as Marxism-Leninism. However, it was difficult to differentiate the cases where MarxismLeninism was used as a theoretical framework (Anweiler 1975; Hans 1964; Price 1974) from cases where it was used for explaining the ideological foundations of the USSR and other countries. $^{14}$

There were exceptions to the general trend of ignoring local knowledges as valuable sources of insights and offering theoretically underdeveloped scholarship. First, two articles illustrated specific theoretical approaches originating in the region: John Zepper (1965)

\footnotetext{
${ }^{12}$ According to the coding system I have used, these are the authors from the USA, Western Europe, Canada, Israel or Australia.

${ }^{13}$ For example, Dobson and Swafford (1980), Grant (1992), Heyneman (1997), Higgins (1976), Janmaat (2007), Kravetz (1980), Mercer and Pogosian (2013), Vogel (1959).

${ }^{14}$ For example, Bigelow (1961), Groth (1987), Judge (1975), Mitter (1987), Raggatt (1977), Roucek (1960), Zajda (1988)
} 
looked at Krupskaya's 'complex principle' which argued that good education should draw on connections between life and work; Bob Caskey (1979) described the pedagogical theories of A. S. Makarenko.

Second, some authors incorporated international and local theories and knowledge into the analysis of educational issues. For example, Murray Yanowitch and Norton Dodge (1968) rely entirely on the local Russian social scientific literature (produced in the modernist tradition) to examine access to post-secondary education by social origin of young people. Another example is an article by Russian authors Elena Lisovskaya and Vyacheslav Karpov (1999) on ideologies in textbooks. The authors develop and adapt some Western theories, using their knowledge of the local context. Namely, they work with a postmodern idea of constellation vs system, based on the writings of Theodor Adorno and Philip Converse. Lisovskaya and Karpov (1999) suggest that there may exist some coherence between the contradictory ideas of westernisation, nationalism, and reinterpretation of communism. Although these ideas do not form a system that is based on logical coherence, they form 'a meaningful ideological constellation that accurately reflects both the common and sectoral interests of the main segments of Russia's political elites.' Thus emerges a new ideology that incorporates conflicting views (Lisovskaya and Karpov 1999). Ann Dryland (1965) used the writing of Karl Popper, John Dewey, and Max Weber when examining how theories of knowledge provided the rationale for educational content, specifically polytechnic and liberal education. The names of Anton Makarenko, Vladimir Lenin, Karl Marx, and Nadezhda Krupskaya are also mentioned in the article.

The discourse of particularity was more popular in the 1950s to 1970s (48\% of all articles producing the discourse of particularity) than in the post-1991 period (36\% of all articles producing the discourse of particularity), while the discourse of universality seems to have become widespread in the last two and a half decades (53\% of all articles developing this discourse were published in this period). The trend of universalising the discourse in comparative education research on post-Soviet countries may point to either more academics being inclined to develop this discourse and/or increasing numbers of peerreviewers and editors prioritising this discourse as more worthwhile. Third, there were two examples of Western authors mentioning local theoretical writing. Vygotsky was mentioned in the article by Avril Suddaby (1989) on teacher-innovators and the paper by Martin McLean and Natalia Voskresenskaya (1992) on education revolution from above; Vissarion Belinsky, Konstantin Ushinsky, Nikolay Chernyshevsky, Nikolay Dobrolyubov, Anton Makarenko, and Nadezhda Krupskaya were referred to in the paper by Jon Judge (1975) on Tsarist and Soviet systems.

\section{Discussion and Conclusion}

The term 'comparative education' was rarely used in educational studies in the USSR; whenever it was used, it referred to the 'bourgeois' educational scholarship produced abroad, as opposed to the 'pure' socialist pedagogical sciences (Nikandrov 1989). The global geopolitics of knowledge has conditioned the nature of comparative research about Soviet and post-Soviet education systems. Western interest in studying Soviet education was fuelled by the Cold War and the surprise launch of the first artificial earth satellite which was an important milestone in the Cold War. Although the original intention was to absorb newlyavailable finances to learn more about the region, about the culture of the people and their approaches to education and training, the articles analysed demonstrated limited engagement with intellectual traditions from outside Europe and North America. The problem with such studies is that they strictly follow the Western academic discourse, thus perpetuating the hegemony and the normative status of Anglo-American and Western European scholarship. 
Most of the studies followed Western frameworks rather than emerging, locally-grounded paradigms. Russia remained the primary regional focus for Western comparative education for decades, leaving other countries in their multi-layered colonial condition.

Considering that we need more CIE scholarship that moves beyond the multi-layered colonial condition, what would be a potential way of moving the field forward?

One opportunity is to think about establishing comparisons between post-Soviet countries and countries of Asia, Latin America, or Africa. There was not a single article analysed making such comparisons. Where comparisons with other countries were involved, the articles analysed compared post-Soviet countries either with one another or the West. This trend may stem from the assumption that post-Soviet countries are rather unique because of the value placed on education, high levels of literacy, and high rates of school enrolment. In future, comparative education knowledge creation will benefit from theory generation based on new patterns of comparisons of post-Soviet countries with transition countries from Asia, Latin America, or Africa, relying on indigenous thought and traditions from these rich Southern contexts.

Another opportunity may lie in more extensive collaborations between local and Western scholars. In an interview with Gita Steiner-Khamsi, Beatrice Beach Szekely describes the US government funded study visit to the USSR in 1978. Both parties displayed interest in the work of the other; however, 'regrettably, their papers did not hit right at the topics we would have liked, but we came close and conversation was frank and more open than ever before' (Steiner-Khamsi 2006a, 20). In the 1950s-1970s, collaboration with Soviet academics might have seemed rather precarious to the academics based in Western countries. Werner Kienitz, the deputy editor-in-chief of the journal published by the Comparative Education Society of the German Democratic Republic, wrote that the book by George Bereday, William Brickman and Gerald Read (1960) produced after a study tour to the USSR was full of prejudices, wrong interpretations and 'fabrications of bourgeois American comparativists' (cited in Steiner-Khamsi, 2006, p. 14). According to Harold Noah, this was not an unexpected reaction as both sides had prejudices towards the other system (Steiner-Khamsi 2006c, 14). Such attitudes continued for many years. Western comparativists who studied socialist systems of education were treated with suspicion; it was all related to the alleged ideological and national biases (Anweiler 1975). Therefore, Oscar Anweiler (1975) predicted that development of collaborative research programmes between Western and socialist colleagues was unlikely in the near future. The dogmatic thinking started to change in the 1980s during perestroika with the Soviet social scientists 'gradually abandoning the paradigm of regarding foreign experience primarily as an object of fundamental criticism' (Malkova et al. 1989). Moreover, Friedrich Kuebart (1989) used the evidence from print media to show that the Soviets were starting to recognise the value of Western research for the image of the USSR abroad. Kuebart also argued that there were more opportunities for academic collaboration and exchange.

The majority of the articles analysed were single-authored. Out of 29 publications that had more than one author, the majority were collaborations between academics in Western countries and only a few articles had authors from a (post-)Soviet country and a Western country; ${ }^{15}$ three of those (Bray and Borevskaya 2001; Bulajeva and Hogan-Brun 2010; McLean and Voskresenskaya 1992) did indeed attempt to complement Western theories and academic tradition with local knowledge in order to analyse educational issues in the

\footnotetext{
${ }^{15}$ For example, Bray and Borevskaya (2001); Bulajeva and Hogan-Brun (2010); Carnoy, Khavenson, and Ivanova (2015); Gershunsky and Pullin (1990); McLean and Voskresenskaya (1992)
} 
transition context. For example, it is argued in one of these articles that 'use of routine solutions and tools that have proven to be effective in Western countries to produce change do not necessarily work in countries under transition, where different ideologies shape aims and scenarios of (educational) reform and practice' (Bulajeva and Hogan-Brun 2010, 80). Academic partnerships between those who possess the local knowledge of such ideologies and speak local language(s) and those who are well-versed in Western academic traditions could be the way forward to generating important changes in the pattern of comparative education knowledge creation that has been overpowered by the rigidity of multi-layered colonialism. Such collaboration will need to focus on generating scholarship that allows us to see how subjugated knowledge from this region can be deployed as an intellectual resource.

\section{Note on contributor}

Maia Chankseliani is Associate Professor of Comparative and International Education at the Department of Education at the University of Oxford, UK. Her research interests focus on education and training policies and practices, and how these influence individual opportunities.

\section{References}

Altbach, Philip G. 1964. "The International Student Movement." Comparative Education Review 8 (2): 131-37.

Anweiler, Oskar. 1965. "The Study of Soviet and East European Education in West Germany." Comparative Education Review 9 (3): 341-45.

- - . 1975. "Towards a Comparative Study of the Educational Systems in the Socialist Countries of Europe." Comparative Education 11 (1): 3-11. doi:10.1080/0305006750110102.

Babones, Salvatore J. 2013. "A Structuralist Approach to the Economic Trajectories of Russia and the Countries of East-Central Europe since 1900." Geopolitics 18 (3): 514-35. doi:10.1080/14650045.2012.748657.

Bailes, Kendall E. 2015. Technology and Society under Lenin and Stalin: Origins of the Soviet Technical Intelligentsia, 1917-1941. Princeton University Press.

Ben-Ari, E, and J van Bremen. 2005. "Asian Anthropologies and Anthropologies in Asia." In Asian Anthropology, edited by Jan van Bremen, Eyal Ben-Ari, and Farid Alatas. Anthropology of Asia Series (Richmond upon Thames, London, England). London: Routledge.

Bereday, George Z. F., William W. Brickman, and Gerald H. Read. 1960. The Changing Soviet School : The Comparative Education Society Field Study in the U.S.S.R. London: Constable.

Bigelow, Karl W. 1961. "Some Comparative Reflections on Soviet and Chinese Higher Education." Comparative Education Review 4 (3): 169-73.

Bodovski, Katerina, Stephen Kotok, and Adrienne Henck. 2014. "Universal Patterns or the Tale of Two Systems? Mathematics Achievement and Educational Expectations in Post-Socialist Europe." Compare: A Journal of Comparative and International Education 44 (5): 732-55. doi:10.1080/03057925.2013.792670.

Bray, Mark, and Nina Borevskaya. 2001. "Financing Education in Transitional Societies: Lessons from Russia and China." Comparative Education 37 (3): 345-65.

Bulajeva, Tatjana, and Gabrielle Hogan-Brun. 2010. "Introducing Early Foreign Language Education in the Baltic Context." Comparative Education 46 (1): 79-97. doi:10.1080/03050060903538715.

Butts, Freeman R. 1968. "International Studies At Teachers College Annual Report For 1967-1968." New York: Teachers College, Columbia University. 
Carey, Henry F., and Rafal Raciborski. 2004. "Postcolonialism: A Valid Paradigm for the Former Sovietized States and Yugoslavia?" East European Politics \& Societies 18 (2): 191-235. doi:10.1177/0888325403259918.

Carnoy, Martin, Tatiana Khavenson, and Alina Ivanova. 2015. "Using TIMSS and PISA Results to Inform Educational Policy: A Study of Russia and Its Neighbours." Compare: A Journal of Comparative and International Education 45 (2): 248-71. doi:10.1080/03057925.2013.855002.

Caskey, Bob. 1979. "The Pedagogical Theories of A. S. Makarenko: A Comparative Analysis." Comparative Education 15 (3): 277-86. doi:10.1080/0305006790150306.

Chankseliani, Maia. 2013. "Rural Disadvantage in Georgian Higher Education Admissions: A MixedMethods Study." Comparative Education Review 57 (3): 424-56. doi:doi.org/10.1086/670739.

- - . 2015. "Escaping Homelands with Limited Employment and Tertiary Education Opportunities: Outbound Student Mobility from Post-Soviet Countries." Population, Space and Place 22 (3): 301-16. doi:10.1002/psp.1932.

Connell, Raewyn. 2007. Southern Theory: The Global Dynamics of Knowledge in Social Science. Cambridge: Polity.

DeWitt, Nicholas. 1964. "Soviet Economic Education." Comparative Education Review 7 (3): 262-66.

Dobson, Richard, and Michael Swafford. 1980. "The Educational Attainment Process in the Soviet Union: A Case Study." Comparative Education Review 24 (2): 252-69.

Dryland, Ann R. 1965. "Polytechnical Education in the USA and the USSR." Comparative Education Review 9 (2): 132-38.

Elliott, Julian, and Jonathan Tudge. 2007. "The Impact of the West on Post-Soviet Russian Education: Change and Resistance to Change." Comparative Education 43 (1): 93-112. doi:10.1080/03050060601162420.

Ferro, Marc. 1997. Colonization: A Global History. London: Taylor \& Francis.

Gershunsky, Boris S., and Robert T. Pullin. 1990. "Current Dilemmas for Soviet Secondary Education: An Anglo-Soviet Analysis." Comparative Education 26 (2-3): 307-18. doi:10.1080/0305006900260212.

Glanzer, Perry L. 2009. "Religion, Education, and the State in Post-Communist Europe: Making Sense of the Diversity of New Church-State Practices." Comparative Education Review 53 (1): 89111. doi:10.1086/593324.

Go, Julian. 2012. "For a Postcolonial Sociology." Theory and Society 42 (1): 25-55. doi:10.1007/s11186-012-9184-6.

Grant, Nigel. 1975. "Developments in Higher Education in the Socialist Countries of Europe." Compare: A Journal of Comparative and International Education 5 (1): 25-33. doi:10.1080/03057927509408814.

-- - 1992. "Education in the Soviet Union: The Last Phase." Compare: A Journal of Comparative and International Education 22 (1): 69-80. doi:10.1080/0305792920220107.

Groth, Alexander J. 1987. "Third World Marxism-Leninism: The Case of Education." Comparative Education 23 (3): 329-44. doi:10.1080/0305006870230307.

Hammersley, Martyn, and Paul Atkinson. 1996. Ethnography: Principles in Practice. 2nd ed. New York: Routledge.

Hans, Nicholas. 1964. "The Soviet Approach to Comparative Education." Comparative Education Review 8 (1): 90-93.

Harris, Dixie Lee. 1963. "Education of Linguistic Minorities in the United States and the U. S. S. R." Comparative Education Review 6 (3): 191-99.

Heyneman, Stephen P. 1997. "Education and Social Stability in Russia: An Essay." Compare: A Journal of Comparative and International Education 27 (1): 5-18. doi:10.1080/0305792970270102. 
Higgins, Janet M. D. 1976. "Problems of the Selection and Professional Orientation of Soviet Pegagogical Students." Comparative Education 12 (2): 157-62. doi:10.1080/0305006760120206.

Hogan-Brun, Gabrielle. 2007. "Language-in-education across the Baltic: Policies, Practices and Challenges." Comparative Education 43 (4): 553-70. doi:10.1080/03050060701611946.

Hufton, Neil R., Julian G. Elliott, and Leonid Illushin. 2003. "Teachers\&\#039; Beliefs about Student Motivation: Similarities and Differences across Cultures." Comparative Education 39 (3): 367-89. doi:10.1080/0305006032000134427.

Jahn, Harvey R. 1975. “USA/USSR: Two Worlds Apart?” Comparative Education Review 19 (3): 45167.

Jankowska, Maja. 2011. "A Reflection on Adaptability, Achievement Motivation and Success of Central and Eastern European Students in One English University." Compare: A Journal of Comparative and International Education 41 (6): 801-18. doi:10.1080/03057925.2011.602536.

Janmaat, Jan Germen. 2007. "The Ethnic 'other' in Ukrainian History Textbooks: The Case of Russia and the Russians." Compare: A Journal of Comparative and International Education 37 (3): 307-24. doi:10.1080/03057920701330180.

Judge, Jon. 1975. "Education in the USSR: Russian or Soviet?" Comparative Education 11 (2): 127-36. doi:10.1080/0305006750110203.

Kappeler, Andreas. 2001. The Russian Empire: A Multiethnic History. Harlow: Pearson Education.

Karakovsky, V. A. 1993. "The School in Russia Today and Tomorrow." Compare: A Journal of Comparative and International Education 23 (3): 277-88. doi:10.1080/0305792930230306.

Kemppainen, Raija Pini, Scott Ellis Ferrin, Steven J. Hite, and Sterling C. Hilton. 2008. "Sociocultural Aspects of Russian-Speaking Parents' Choice of Language of Instruction for Their Children in Estonia." Comparative Education Review 52 (1): 93-119. doi:10.1086/524043.

Khalid, Adeeb. 2007. "Introduction: Locating the (Post-) Colonial in Soviet History." Central Asian Survey 26 (4): 465-73. doi:10.1080/02634930802017895.

Kissane, Carolyn. 2005. "History Education in Transit: Where to for Kazakhstan?" Comparative Education 41 (1): 45-69. doi:10.1080/03050060500073249.

Kołodziejczyk, Dorota, and Cristina Şandru. 2012. "Introduction: On Colonialism, Communism and East-Central Europe - Some Reflections." Journal of Postcolonial Writing 48 (2): 113-16. doi:10.1080/17449855.2012.658242.

Korbits, Keit. 2014. "The Representation of the Cold War in Three Estonian History Textbooks." Compare: A Journal of Comparative and International Education 0 (0): 1-20. doi:10.1080/03057925.2014.917948.

Kravetz, Nathan. 1980. "Education of Ethnic and National Minorities in the USSR: A Report on Current Developments." Comparative Education 16 (1): 13-23. doi:10.1080/0305006800160103.

Kuebart, Friedrich. 1989. "Soviet Education and Comparative Research-a German View." Comparative Education 25 (3): 283-92. doi:10.1080/0305006890250304.

Kuwayama, Takami. 2004. Native Anthropology: The Japanese Challenge to Western Academic Hegemony. Japanese Society Series. Melbourne, Vic: Trans Pacific.

Lazarus, Neil. 2012. "Spectres Haunting: Postcommunism and Postcolonialism." Journal of Postcolonial Writing 48 (2): 117-29. doi:10.1080/17449855.2012.658243.

Levačić, Rosalind. 2014. "Using Quantitative Data in World Bank per-Student Funding Reform Projects: Data, Designs and Dilemmas in Transition Countries." Comparative Education 50 (3): 1-17. doi:10.1080/03050068.2014.921373.

Lisovskaya, Elena, and Vyacheslav Karpov. 1999. "New Ideologies in Postcommunist Russian Textbooks." Comparative Education Review 43 (4): 522-43. 
Malkova, Z.A, Nikolai D. Nikandrov, B.S Gershunskii, and V.S Shubinskii. 1989. "Pedagogicheskaya Nauka Na Novom Etape (Pedagogical Science at a New Stage of Development)." Sovetskaya Pedagogika 1: 40-46.

Marginson, Simon, and Marcela Mollis. 2001. "'The Door Opens and the Tiger Leaps': Theories and Reflexivities of Comparative Education for a Global Millennium." Comparative Education Review 45 (4): 581-615. doi:10.1086/cer.2001.45.issue-4.

McLean, Martin. 1992. The Promise and Perils of Educational Comparison. London: Tufnell.

McLean, Martin, and Natalia Voskresenskaya. 1992. "Educational Revolution from above: Thatcher's Britain and Gorbachev's Soviet Union." Comparative Education Review 36 (1): 71-90.

Medlin, William K., and William M. Cave. 1964. "Social Change and Education in Developing Areas: Uzbekistan." Comparative Education Review 8 (2): 166-75.

Mercer, Justine, and Victoria Pogosian. 2013. "Higher Education Leadership in Russia: A Case Study of Mid-Level Academic Management at an Elite State University." Compare: A Journal of Comparative and International Education 43 (2): 184-202. doi:10.1080/03057925.2012.685585.

Mitter, Wolfgang. 1973. "On the Efficiency of the Soviet School System." Comparative Education 9 (1): 34-47. doi:10.1080/0305006730090105.

- - . 1987. "The Teacher and the Bureaucracy: Some Considerations Concluded from a Soviet Case." Compare: A Journal of Comparative and International Education 17 (1): 47-60. doi:10.1080/0305792870170106.

- - . 2004. "Rise and Decline of Education Systems: A Contribution to the History of the Modern State." Compare: A Journal of Comparative and International Education 34 (4): 351-69. doi:10.1080/0305792042000294788.

Moore, David. 2006. "Is the Post- in Postcolonial the Post- in Post-Soviet?: Toward a Global Postcolonial Critique." In Baltic Postcolonialism, edited by Violeta Kelertas. New York: Rodopi.

Nikandrov, Nikolai D. 1989. "What to Compare, When and Why: A Soviet Perspective." Comparative Education 25 (3): 275-82. doi:10.1080/0305006890250303.

Noah, Harold J. 1984. "The Use and Abuse of Comparative Education." Comparative Education Review 28 (4): 550-62.

Oleksiyenko, Anatoly. 2014. "On the Shoulders of Giants? Global Science, Resource Asymmetries, and Repositioning of Research Universities in China and Russia." Comparative Education Review 58 (3): 482-508. doi:10.1086/676328.

Perveen, Talat. 1987. Growth of Soviet Technical Intelligentsia (1917-1953). Mittal Publications.

Petherbridge-Hernandez, Patricia, and Rosalind Latiner Raby. 1993. "Twentieth-Century Transformations in Catalonia and the Ukraine: Ethnic Implications in Education." Comparative Education Review 37 (1): 31-49.

Poppleton, Pam, Boris S. Gershunsky, and Robert T. Pullin. 1994. "Changes in Administrative Control and Teacher Satisfaction in England and the USSR." Comparative Education Review 38 (3): 323-46.

Price, R. F. 1974. "Labour and Education in Russia and China." Comparative Education 10 (1): 13-23. doi:10.1080/0305006740100103.

Raggatt, Peter. 1977. "School and Work: Some Ideological Considerations." Compare: A Journal of Comparative and International Education 7 (2): 83-91. doi:10.1080/0305792770070202.

Rosen, Seymour M. 1964. "Problems in Evaluating Soviet Education." Comparative Education Review 8 (2): 153-65.

Roucek, Joseph S. 1960. "Juvenile Delinquency and Crime in the Soviet Bloc." Comparative Education Review 3 (3): 40-47.

Silova, Iveta, Mark S. Johnson, and Stephen P. Heyneman. 2007. "Education and the Crisis of Social Cohesion in Azerbaijan and Central Asia." Comparative Education Review 51 (2): 159-80. doi:10.1086/509592. 
Steiner-Khamsi, Gita. 2006a. "An Interview with Beatrice Beach Szekely." European Education 38 (4): 8-22. doi:10.2753/EUE1056-4934380401.

- - . 2006b. "The Development Turn in Comparative Education." European Education 38 (3): 1947. doi:10.2753/EUE1056-4934380302.

- - . 2006c. "U.S. Social and Educational Research During the Cold War: An Interview with Harold J. Noah." European Education 38 (3): 9-18. doi:10.2753/EUE1056-4934380301.

Suddaby, Avril. 1989. "An Evaluation of the Contribution of the Teacher-Innovators to Soviet Educational Reform." Comparative Education 25 (2): 245-56. doi:10.1080/0305006890250210.

Takayama, Keita. 2011. “A Comparativist's Predicaments of Writing about 'other' Education: A SelfReflective, Critical Review of Studies of Japanese Education." Comparative Education 47 (4): 449-70. doi:10.1080/03050068.2011.561542.

Tomiak, Janusz. 1986. Western Perspectives on Soviet Education in the 1980s. Studies in Russia and East Europe. Basingstoke, Hampshire: Macmillan, in association with the School of Slavonic and East European Studies, University of London.

Trace, Arther S. 1961. What Ivan Knows That Johnny Doesn't. Westport, Conn: Greenwood Press.

Vogel, Albert W. 1959. "Indoctrination of Teachers of English in the Soviet Pedagogical Institute." Comparative Education Review 3 (2): 32-35.

Wallerstein, Immanuel. 1976. "Semi-Peripheral Countries and the Contemporary World Crisis." Theory and Society 3 (4): 461-83. doi:10.1007/BF00161293.

Wiloch, J. Tadeusz, George Z. F. Bereday, and Christina Gidynski. 1959. "New Models in Soviet Education." Comparative Education Review 3 (2): 5-13.

Worden, Elizabeth Anderson. 2011. "The 'Mock Reform' of History Education in Moldova: Actors versus the Script." Comparative Education Review 55 (2): 231-51. doi:10.1086/657999.

Yanowitch, Murray, and Norton Dodge. 1968. "Social Class and Education: Soviet Findings and Reactions." Comparative Education Review 12 (3): 248-67.

Zajda, Joseph. 1979. "Education for Labour in the USSR." Comparative Education 15 (3): 287-99. doi:10.1080/0305006790150307.

-- . 1988. "The Moral Curriculum in the Soviet School." Comparative Education 24 (3): 389-404. doi:10.1080/0305006880240310.

Zepper, John T. 1965. “N. K. Krupskaya on Complex Themes in Soviet Education.” Comparative Education Review 9 (1): 33-37. 